\title{
ANGLO-SAXON OTHERS IN THE SPANISH IMAGINATION
}

\author{
Paloma Tejada Caller
}

\section{Universidad Complutense de Madrid}

ptejadac at filol ucm es

\begin{abstract}
This paper aims to contribute to contemporary research on Spanish images of Englishness and thus on cross-cultural otherness. More precisely, it seeks to identify and describe the composite image of Anglo-Saxon Others as portrayed in ten nineteenth century Spanish history books and to critically discuss the results.

Despite Anglo-Saxon England being a marginal issue for nineteenth century Spanish scholarship, it has been proved that existing narratives constitute seminal representations of Anglo-Saxon identity and serve a neatly defined heterogeneous array of political and collective aims ${ }^{1}$. The present analysis suggests that the portrayal of Anglo-Saxon Others contributes to reinforce the ideological bases on which the Anglo-
\end{abstract}

\footnotetext{
${ }^{1}$ This paper was funded by the Spanish Ministry of Education. Project MICINN-FFI2011-24172.
}

Tejada Caller, Paloma. 2012.

Anglo-Saxon Others in the Spanish imagination.

Círculo de Lingüística Aplicada a la Comunicación 51, 82-104.

http://www.ucm.es/info/circulo/no51/tejada.pdf DOI http://dx.doi.org/10.5209/rev_CLAC.2012.v51.40629

(C) 2012 Paloma Tejada Caller.

Círculo de Lingüística Aplicada a la Comunicación (clac) 51, 82-104.

Universidad Complutense de Madrid. ISSN 1576-4737. http://www.ucm.es/info/circulo 
Saxons themselves are built and reveals the tensions which result from the multiple functions performed by the narratives selected. More in particular, the narratives analysed will be shown to differ according to the degree of detail with which the AngloSaxon Others are described, and to roughly conform to the Roman vs Germanic traditions recognised among Anglosaxonists. The tradition a given historian belongs to seems to determine not only the features chosen to represent the Anglo-Saxon Others, but also the number of groups that should be defined as such. Most interestingly, a different concept of race appears to emerge from either ideological platform.

From a more general standpoint, this research enhances our understanding of the symbolic nature of stereotypes as created in narratives of major social institutions which maintain a relationship of expert-novice with their audiences. Last but not least, this paper opens up new areas of inquiry for future research.

Keywords: Anglo-Saxon, cross-cultural identity, 19th century Spain, Englishness.

\section{Contents}

1. Introduction 84

2. The present analysis: description of corpus 84

3. Vindication of the Middle Ages and the Anglosaxonists' traditions 88

4. Representation of Anglo-Saxon Others: analysis of results 91

5. Concluding remarks 99

References 100

Primary Sources 103 


\section{Introduction}

Though Anglo-Saxon England undoubtedly represents a marginal issue for nineteenth century Spanish scholarship, it has also been proved that existing narratives constitute seminal representations of Anglo-Saxon identity and serve a neatly defined heterogeneous array of political and collective aims. In matters of identity the majority opinion still holds that self-identity cannot be understood without the interaction of (conventionally negative) Others ${ }^{2}$. Thus, the present analysis is grounded on the hypotheses that: a) the portrayal of Anglo-Saxon Others will contribute to reinforce the Anglo-Saxon identity envisaged in Spanish sources and the ideological and discursive bases on which the Anglo-Saxons themselves are built; b) this reinforcement will be stronger as created in narratives of major social institutions which maintain a relationship of expert-novice with their audiences. More precisely, the role played on the creation of an Anglo-Saxon identity by the constructed image of Others will prove most relevant in history school and university handbooks from the mid century onwards. And c) these images of Others will be affected by the ideology of historians.

\section{The present analysis: description of corpus}

As illustrated in Table I, a corpus of ten general-reference and history books, meant for the education or instruction of different audiences and published between the 1820s through the 1890s, were selected to prove our hypotheses. Explicitly, an early geographical treatise or “ordered synthesis of the world”, intended for diplomats and learned readers (Torrente 1927-8) ${ }^{3}$; two unauthored books of general reference

\footnotetext{
${ }^{2}$ For the Spanish construction of an Anglo-Saxon identity, see Tejada 2011a. Literature on the discursive construction of identity is extensive. Suffice it to mention here Bourdieu, 1980, Anderson, 1991, Corbey et al. eds. 1991, Delanty 2008; Leary \& Tangney 2003, Leersen 2006, van Dick 2008, Wodak et al. eds., 2009, etc. As for European views of Englishness, see Nünnig 2004, Tejada 2005 and Xenographies Conference Proceedings.

${ }^{3}$ The contents in Torrente 1927 are organised into two volumes: in the first one, information concerning countries is topically ordered: physical geography, climate, natural curiosities, political relations, religion, primitive population, habits, literature and languages, etc. In the second volume, a historical account of each country is offered.
} 
(Enciclopedia de la Juventud $1825^{4}$, where the intervening role of the translator is openly acknowledged in the title, and Celebridades del mundo $1846^{5}$ ); and seven history textbooks devised for primary school children (Basté 1888); secondary school children (Gómez Ranera 1871, Gaite 1874 and Moreno Espinosa 1881) and university students (Castro 1863-72, Góngora 1882 and Puente Villanúa 1875).

Table I: Chronological audience-based distribution of selected texts

\begin{tabular}{|l|l|l|l|l|}
\hline Audience & $\mathbf{1 8 2 0 - 1 8 4 5}$ & $\mathbf{1 8 4 5 - 1 8 7 5}$ & $\mathbf{1 8 7 5 -}$ \\
\hline Diplomats & Torrente & & \\
\hline Youth & $\begin{array}{l}\text { Enciclopedia de la } \\
\text { Juventud }\end{array}$ & & Celebridades & \\
\hline General readers & & Gaite & Gómez & Moreno Espinosa \\
\hline 1ary education & & Ranera & Basté \\
\hline 2ary education & & Castro & Góngora & Puente \\
\hline education & & & Villanúa \\
\hline
\end{tabular}

\footnotetext{
${ }^{4}$ A little ambitious multi-volume general reference book, the Enciclopedia is devised for hardly literate young readers and "schoolchildren of both sexes". It follows a question-and-answer scheme or that of a chronological table.

${ }^{5}$ Celebridades, also titled A “Chronology of universal history” was intended to raise a general audience's “awareness towards social and religious advances”.
} 
The chronological distribution of the selected texts responds to a rough division of the Spanish nineteenth century, echoing substantial political or cultural events (Carr 1969, Artola 1973). Up to the 1840s Spain goes through a period of political and social unrest, fluctuating alternatively between the mutually exclusive movements of absolutism and liberalism. The 1840s and 1850s constitute a stage of consolidated liberalism. The so called bourgeois revolution gets to its peak and Spain sees herself full of hope, strong and in transformation, though the effects of the past keep still refraining the institutional and socio-economic reforms needed. It is at this stage that a larger influence of foreign thought through translations must be noticed (Tejada 2011c). From the late 1860s to the mid 1870s the new constitution emerged from the 1868 revolution allows for the country to enjoy a greater freedom of conscience and religious practice, and a clearer adherence of intellectuals to the European trends is perceived. Finally, from the $1875 \mathrm{~s}$ Spain undergoes yet another period of restrictions to freedom in all orders of life.

A second chronological issue seems worth mentioning for a full understanding of the corpus and the importance conferred to history books. The fact that from the 1860s history acquired an academic nature in our country meant that history books and books of general reference with a historical base acquired political and social relevance, since history became a component of socialization and national identification of future citizens (Peiró 1990, 1993; Valls 1999; García Puchol 1993) ${ }^{6}$. Moreover, it must be noticed that heterogeneous groups of illustrated scholars frequently developed into professional historians. Through "interpretive acts of retrospective appropriation" (Laden 1999: 73), they were most likely to taint official textbooks with their own religion, class, age and ideological preconceptions. As a consequence, these affiliations and alliances expressed in the public forum of publication would affect the selection of contents, the space devoted to figures and events, as well as the historiographical methods and strategies employed.

\footnotetext{
${ }^{6}$ Up to the 1840s history writing constituted a bourgeois professional practice, the task of intellectuals, politicians, lawyers, journalists, military or religious people and other men of letters, who wrote vocationally.
} 
As for the voices responsible for the selected writings, a bio-sketch of the authors will serve our goals. Nevertheless, it should be noticed that the available information varies notably from scholar to scholar ${ }^{7}$.

Following the order of appearance in Table I, Mariano Torrente was an economist and translator, holding important political and diplomatic posts throughout his career. Considered an "afrancesado", , he spent part of his life in Cuba. Basté y Serarols was a primary school teacher, whose poor handbook was however widely distributed in Spain and Spanish-speaking countries. As for Joaquin Gaite y Nuñez, a medical doctor, journalist and vocational historian, he taught at the Centro de Instrucción Provincial de Enseñanza Secundaria de Orense, a reputedly important cultural centre in the city from 1845 onwards, where English was taught. Few data are left from Alejandro Gómez Ranera, whose name does not figure in common catalogues of historians. He is known to have written official education textbooks for secondary students during the 1870s and 1880s. Born in Cebreros (Ávila), Alfonso Moreno y Espinosa graduated in Filosofía y Letras at the Universidad Central de Madrid and was deeply influenced by his master Julián Sanz del Río, a relevant krausista and regenerationist. In 1867 he began working as a Geography and History secondary school teacher in Instituto Columela (Cádiz). Aiming to change the Spanish political, social and moral situation from within and a friend of Castro's, he was accused of defending anti-Christian ideas in a Christian disguise. Fernando de Castro, probably the most influential and well-known author of the group, was a krausista ${ }^{9}$, a renowned liberal and a heterodox catholic showing a recurrent optimistic faith in human progress, an open concern about Spanish affairs, and

\footnotetext{
${ }^{7}$ The two unauthored books included in the corpus, Enciclopedia and Celebridades del Mundo, were both translations from French adapted to Spanish needs. For information on Zaragoza Godínez, the translator of the Enciclopedia, the reader is referred to Delgado (1975) and Alonso (2007).

8 “Afrancesado” is a pejorative term used in 18th century Spain for admirers of French culture. It acquired political connotations of treason. Many of them went into exile.

${ }^{9}$ Krausista. A follower of a regenerationist political doctrine, slightly based on the ideas of the German philosopher Krause, as introduced in nineteenth century Spain by Julián Sánz del Río.
} 
a wish for reform and for a new approach to history and the public description of nations. He held a Professorship in Spanish Literature in Madrid. Manuel de Góngora y Martínez, the closest to the so called traditionalist standpoints (Baena 2003: 362), maintained that man is an essentially cultivated being. Propounding that Christianity is equivalent to civilization, his is the clearest example of textbooks aiming to demonstrate and celebrate the triumph of Christianity over paganism. Finally, José Puente y Villanúa, a well known writer and man of letters, graduated in Philosophy and Law. He began his career as a history teacher in a private school to become a Professor of Spanish literature in Oviedo and Zaragoza. As a neocatólico (liberal catholic), he aimed at the restructuring of Spain through the combination of Christian principles with Enlightment ideas.

\section{Vindication of the Middle Ages and the Anglosaxonists' traditions}

The fact that the Middle Ages constituted a vindicative time for Spanish groups of competing ideologies, who aimed at controlling the popularization of the past among a hardly literate nineteenth century society, seems of particular relevance for our research. As put forward elsewhere (Tejada 2011b), the Middle Ages stirred up the interest of both conservative and progressive sectors of Spanish society, either as a period of highlighted Christianity or as a transition stage between the ancient times and modernity ${ }^{10}$.

This twofold stand maintained on the Middle Ages by Spanish historians might be paralleled to the Roman vs Germanic traditions of Anglosaxonists, as traditionally recognised (Frantzen 1990, Åström 2002). Thus, historians defending the Middle Ages as a period of highlighted Christianity might be identified with a more conservative Roman heritage, whereas those who saw the Middle Ages as a transition stage between the ancient times and modernity might be said to belong to an (impure or modulated)

\footnotetext{
${ }^{10}$ The influence of writers such as Tierry or Guizot from the 1830s should not be disregarded here.
} 
Germanic tradition ${ }^{11}$. In this regard, it should be borne in mind that progressive historians aiming to foster deep changes into the Spanish political and cultural scene took Great Britain as their model and would hence be apt to subscribe a Germanic view of the English medieval period ${ }^{12}$. Following that line of reasoning, a more detailed analysis of each perspective would not only contribute guidelines to structure our different representations and the features attributed to those conceptualized as AngloSaxon Others in Spanish writings, but would enhance our understanding of the number of groups actually depicted as their Others.

Concerning the differences between the Roman and the Germanic traditions, some well established standpoints may be recalled. As it is known, the so-called Roman historians would dissociate themselves from the uncivilized, unchristian Anglo-Saxons, depicting the Germanic and, therefore, the medieval English ancestors as primitive and barbaric savages. Germanic historians, on the contrary, propounded an idealized vision of the Germanic past. Along the lines of Tacitus' Germania they would render the image of a Germanic society mainly martial in its outlook, simple and straightforward, and defined by ideals of honesty, loyalty and truth, or as Roberta Frank (1991: 104) phrases it: “[t]o some extent we still share with Tacitus an idealized vision of the Germanic past, of a northern frontier brimming with simple, loyal, brave, proud and warlike pagans, men who were everything the materialistic, intellectual, cosmopolitan Romans were not.”

However, a deeper insight into that academic dichotomy leads to remarkable inferences useful for our work, as they affect the identification and conceptual qualification or the Anglo-Saxon Others and, most interestingly, their number. That is, the revision of the

\footnotetext{
${ }^{11}$ It is not to be forgotten that Spain has always been bound to her Roman and Christian ancestry and that representatives of the progressive sectors (krausistas, neocatólicos close to French or Belgian schemes, and more radical critics against the Church) were usually out of the political and institutional spheres. Concurrently, though radical versions of the Germanic tradition have been acknowledged in England, more intermediate positions have also existed among English Anglosaxonists. (Åström 2002: 63, quoting Frantzen 1990).

${ }^{12}$ Castro (1863-1872: vol II, 47) himself distinguished between germanistas and no germanistas in his writings.
} 
two-fold approach helps structuring the challenge against well-established assumptions perceived in some of the selected texts.

As can be expected, Germanic Anglosaxonists support the view that classical virtues should not be taken for granted. Rome is portrayed as a paradigm of degeneration and its legacy is not identified with that of a superior culture brutalised by the inferior, barbaric Anglo-Saxons. Moreover, England is not conceived of as part of the continent, broken apart from it by furious barbarians. The ideas that Rome's decline spans the ninth century and that the Viking impact constituted a re-run of the fifth-century barbarian onslaught seem also shattered under that paradigm. This implies that Rome may be questioned and, thus, othered.

Under these circumstances, the praising of Germanic singularity and virtues runs parallel to the Roman downplaying. From the Germanic approach to the Anglo-Saxons, Britain's nineteenth century supremacy and grandeur was preordained, the country owing it to their primitive Germanic ancestors ${ }^{13}$. This being so, it seems easy to accept not only England's geographic significance from the outset (over that of Rome), as is claimed (Lavezzo 2006), but the relevance of the Anglo-Saxons. From this tenet, however, new questions arise: would the Vikings be identified as sibling ninth- century Germanic heirs contributing to the same cause as the Anglo-Saxons? Could this also be asserted of the ultimately Germanic Normans? Or will these peoples, conversely, be catalogued as Anglo-Saxon opposing Others deprived of their ancestral virtues?

Religion is another point in focus interfering with heritage and major traits of group identity. Establishing the equivalence between religion and civilization and that between Christianity and the Church, Anglosaxonists under a Roman tradition encourage the idea that all Christians constitute a single race. Apart from further assumptions, this

\footnotetext{
${ }^{13}$ Very much in accordance with the so-called Whig view of history, popularized by Lord Macaulay, which presents the past as an inexorable process towards more advanced states.
} 
makes race a matter of religion, a view probably alien to opposing standpoints. Furthermore, the unarguable nature conferred to Christianity as a binding link may be said to affect the interpretation of territorial identity. Given the fact that Christians seem to possess a godly right to exclude temporary (pagan) winners of land, the need to forget certain historical stages as uninteresting and barren proves justified.

This brief outline allows us to elaborate on our hypotheses on Anglo-Saxon Others. The lines of argument sketched above may directly impinge on the portrayed image of Anglo-Saxon Others. But what is most significant, they may affect the number of Others under consideration. The list of Anglo-Saxon opponents would traditionally just encompass the Celts and the Vikings. But it seems most likely that depending on the historian's point of view the inventory may be enlarged by at least two more groups: the Normans and the Church as an institution, which in turn would include the Romans, as ancestors of a Christian heritage.

\section{Representation of Anglo-Saxon Others: analysis of results}

Taking the previous parameters into account, in this section information on four groups of peoples was analysed as pertaining to potential Anglo-Saxon Others: Celts, Vikings, Normans, and the Church as an institution. The portrayal of Germanic barbarians was necessarily considered as well, so as to determine the extent to which ninth century invaders were identified with their acclaimed or disapproved ancestors. Aspects of a more general nature concerning the original approach were also observed.

Hence results from the analysis are organized as follows. First, observations of a more global character are given. A second subsection will be devoted to the differences between the Roman and the Germanic standpoints. Finally a characterization of the individual groups of Anglo-Saxon Others will be offered. Precise information is included in Appendixes I and II. 
From a most general point of view the analysis of the different narratives shows that the Anglo-Saxons are actually defined in terms of their difference from the Others. The Others are always mentioned and often clearly singularized and characterized. The term "nation” is recurrently used and "foreign” conveys a negative sense. Suffice it to say that Castro (1863-1872, vol III: 193) refers to the Normans as being a foreign race; in Gómez Ranera (1871: 168) the Celts are described as a group of uncertain origin; and the Vikings are represented as foreign, brutal and cruel (Castro 1863-1872, vol II: 34154), foes, conquerors and pirates (Moreno 1881: 201) or foreign pirate invaders (Góngora 1882: 50, 127) ${ }^{14}$.

The records may be also said to differ according to the degree of detail with which the Anglo-Saxon Others are described. An increasing detail is observed as we move closer to texts targeted to educated audiences and apart from a general or illiterate readership. A close representation of the Anglo-Saxon Others seems to be most fruitful in the official education of future citizens or elites, considering the potential of their action. In this respect, Basté devotes a scarce few words to the Celts, whereas Puente or Castro expand their comments into further detail. Proportionally this is maintained with regard to all Other groups, Castro being the most profuse in his argumentation and the Enciclopedia, Celebridades, Torrente and Basté the least.

As regards questions concerning the differences between ideological stances, the study reveals that the Spanish narratives on Anglo-Saxon Others may be assumed to roughly conform to the two different traditions recognised among Anglosaxonists: Roman vs Germanic. This split nevertheless does not prove categorical, a question of "either/or, and a two-pole cline should rather be acknowledged. The Germanic tradition is never pure in Spain and most narratives show the intersection of traditions. Accordingly, closer to the Roman pole are Góngora and Gaite, followed by Gómez Ranera, Basté, Enciclopedia, Celebridades and Torrente. Conversely, towards the Germanic end the names of Puente, Moreno and, most clearly, Castro must be brought up.

\footnotetext{
${ }^{14}$ Renderings of the original texts are mine.
} 
As expected, the analysis suggests that the tradition a given historian belongs to determines not only the features chosen to represent the Anglo-Saxon Others, but also the number of groups that should be defined as such.

Closer to the Roman pole are historians who emphasize the Others' image of uncivilized, unchristian peoples, a characterization which even affects the Celts in Gómez Ranera, where they -“weak”, “pitiful”, “useless defenders of their land”- are asserted to have their own non-Christian religion.

Texts such as Celebridades, Gómez Ranera’s, Gaite’s and, especially, Góngora’s quite consistently equate religion with civilization and confirm Christianity as the only means of transformation (Gómez Ranera 1872: 170; Gaite 1874: 255; Góngora 1882: 48). Paganism is directly linked with guilt and error. Cruel Germanic actions are explained as due to these peoples' bloody cult of Odin (Gaite 1874:313), to their being ardent pagans opposed to the Christian faith (Puente 1875: 29), or to have their fierceness undiluted by Christianity (Góngora 1882:10). The Christian religion and its representatives -Charlemagne, Edward Confessor- are routinely highlighted or praised $^{15}$. Consequently, placing their focus on religious continuity these texts present the idea that both the Germanic and the Anglo-Saxon periods have little to recommend them and should pass unnoticed.

Though Góngora and Gómez Ranera recognize some virtues to the ancient (later despised or lost) Germanic race, texts closer to the Roman construal of Anglo-Saxon Others emphasize the fact that the ninth century Viking advent constitutes a re-starting of the vicious invasions which took place four hundred years before ${ }^{16}$.

\footnotetext{
${ }^{15}$ Contrary to this strategy, Torrente puts little emphasis on religion. For Puente (1875: 31), Castro (18631872: vol. III, 92, 93; vol. II, 356) and Moreno (1881: 158) paganism is described as a mere fact, a natural feature of ancient times, or as part of the Germanic culture mirroring their habits and simplicity of life.

${ }^{16}$ Gómez Ranera (1871: 142-3) devotes a lengthy paragraph to describing the Germanic culture, emphasizing their "love of justice", "honesty in their dealings", "bravity against Rome" and further details. In his university textbook Góngora (1882:12-3), in turn, also mentions the "individual freedom”, "inborn bravity", "virginal character" and "readiness to sacrifice” qualifying these "men of honour”. It
} 
For that same reason, the desired survival of Christianity also filters the image projected on the Normans in books such as Enciclopedia (1825-6, vol 2: 302), Torrente (1827-8, vol 2: 208), Celebridades (1846) or Basté (1888: 109), although surprisingly not in Gongora's (1882: 141) or Gaite's (1874: 288). Their advent allowing England to recover her continental and Christian links is expectedly celebrated.

Within this conservative frame the Anglo-Saxons and their Others are usually given a territorial identity as temporary land winners and owners. Land control, the physical possession of tangible territory, leads identity. However, land property rights are hierarchically understood. The more morally justified an incoming group, the stronger their rights of exclusion. Thus, non-lasting territorial identities, such as those of the Celts, the Anglo-Saxons or the Vikings are rendered peripheral to historical record, a strategy with which the much hyped English singularity becomes deemphasized.

From what has been said up to now it may be easily inferred that in Spain conventional historians used their narratives on Anglo-Saxon Others either to reinforce radical Catholic standpoints or to justify the religious-based prevailing culture.

Closer to the Germanic pole lie those historians who claim for the introduction of progressive -political, social and educational- polities, focussing on Anglo-Saxon England as a praised and desired model, as hinted above. Authors such as Puente, but especially Moreno and Castro, share an idealized vision of the Germanic past and highlight its singularity and current interest.

These historians, who render the Anglo-Saxons as the seed of a powerful and brilliant nation, portray both the Vikings and the Normans as chief Others, particularly wicked and brutal against their enemies. The Anglo-Saxons, thus, become represented as victims, singled out, different and better. That is probably the reason why in their texts there is no trace of identification between an idealized fifth century and the later Germanic arrivals. In this case, ethnic nearness does not exclude otherness. As will be 
shown further below, both groups of people are severely ousted by writers such as Moreno or Castro. Moreover, it seems that the exaltation of past and noble ancestors is devised as a mechanism for displacing blame from real warriors of the Anglo-Saxon period.

In Puente’s, Moreno's and Castro's retellings the representation of Others seems at the service of the writers' own desires for a new beginning. Virtues such as peace, democracy, federalism, local respect, the prospect of a contractual monarchy, the mixture of cultures, even the need of a true and uncorrupted Christian faith are brought up in a variety of contexts, be it describing the Germanic peoples, the figure of Cnut, the role of Christianity, biased actions of the Church or William I's ruling behavior (Puente 1875: 8, Moreno 1881: 159; Castro 1863-1872, vol II: 48-65). The writers' claim seems to be that religion is not the only tool to shape the nation and that worldly politics also plays a role in identity construction.

Consequently and most interestingly to our purposes, assimilation appears to be a crucial notion among progressive historians contributing to the ethnic identity of a group of people facing a brilliant collective destiny. For historians holding a Germanic stance, the Others are no longer others if they assimilate to the Anglo-Saxons, be they Celts, Vikings or Normans. Race is hereby revealed as a matter of allegiance, as though in-migration (in terms of cultural exchange and transformation) would shape the nation. Race might be understood as a process guided by a people's collective destiny. In sum, for these writers the once-Others may dynamically opt in. That new perception of race affects religion too, it being considered as a means of social adaptation, rather than a directive for individual or political 'reorientation'. Religion might metaphorically be grasped as another "opting-in migrant”, contributing to a better and more civilized future.

Last in this section, considering out-groups as individually described in the selected texts, results ratify that the Celts receive a homogeneous image throughout. They constitute a weak and shadowy Other, territorially identified, contributing to round up the representation of a powerful and primitive people (the Anglo-Saxons), rightful 
inheritors or owners of their land. They may even be identified with other distant barbarians, with their own non-Christian religion and their unknown origin.

The Vikings also receive a consistent image from both groups of historians. Externality, lawlessness and violent expropriation remain the key ideas, though their representation may stress either their pagan or their brutal side, depending on the historian's ideology and goal $^{17}$. Nevertheless some contrasting nuances between conventional and regenerationist texts may be observed. For historians leaning towards the Roman end of the cline, the Vikings serve as the stereotype of the evil Germanic barbarians, as expected. However, though in more progressive narratives the Vikings are also rendered as the near and wicked Anglo-Saxon other, it is also true that they are often granted a more complex image, where those who assimilate and opt in to share the glorious future of the new group are “atoned”. In other words, the Vikings are not systematically depicted as a monolithic group ${ }^{18}$. In successive occasions Castro's detailed account refers to Vikings who "opted in for conversion"; to "Vikings allied to Bretons"; he distinguished between "Vikings" and "pirates", spoke about "pacific Danes” and made allusion to some "peaceful and industrious” subgroups (Castro 1863-1872: vol. II, 346, 354-5; vol III, 191). Along the same lines, Moreno (1881: 202-3) mentions the presence of assimilated groups of Vikings who adopting the Christian religion "accepted to live in peace” and praises Cnut's efforts to mix cultures.

It is worth noting that within this Viking out-group Cnut becomes a main and controversial character, either praised or criticized. Thus, he may be perceived as a “Christian and loving king” (Góngora 1882: 129), as a “just and loved king” (Gaite 1874:257), as “a peace-maker promoting links with the continent” (Puente: 1875: 88),

\footnotetext{
${ }^{17}$ For Gaite the Vikings prove "pagan and cruel”, “fierce idolaters”; Góngora (1882: 50, 127) describes them as "primitive, offensive against religion", their "bloody religion" being not "the real and true civilization”. In Castro (1863-1872, vol II: 341-54, vol. III: 190) labels such as “invading”, “looters”, “foreign”, “brutal”, “cruel”, “invincible conquerors”, “destroyers”, “greedy”, “menacing”, “demanding”or “offensive” are used. For Moreno (1881: 201), they are “foreign”, "pirates”, “enemies of society”.

${ }^{18}$ For another unconventionally subtle description of a primitive people, see Tejada 2009.
} 
as "a cruel and vengeful tyrant submissive to the Church" (Castro 1863-1872, vol III: 190)) or as “a leader successful at cultural fusion” (Moreno 1881: 203).

Contrary to the homogeneous images of Celts and Vikings in the texts, findings indicate that the historian's stance determines the characterization of a third other. The Normans receive a heterogeneous image, either positive or negative, depending on the writer's ideological tradition. It seems that the Normans' highlighted features are intended to round up the image profile assigned to other Anglo-Saxon strangers in each narrative. Hence, this group is usually praised by Roman-heritage historians ${ }^{19}$. From this standpoint, the Normans are given the territorial right of land winners, are justified in their action against the weak, coward and disloyal Anglo-Saxons and recognised as duly victors for their civilising results (Enciclopedia, Torrente, Basté, Celebridades, and Gómez Ranera) ${ }^{20}$. In sum, opposite to the prototypical negative notion of Other, the Normans in these narratives would not be categorised as such.

As for historians favouring a Germanic viewpoint, the Normans are rendered a more negative image, highlighting the complete breach of traditions caused by their arrival. Puente's poor representation focuses on the power of an army of unlawful usurpers (1875: 89). For Moreno (1881: 203) this foreign, cruel and exterminating people did not fulfil their expected political role of national integration. And Castro (1863-1872: vol. III, 201-3), in turn, criticises their untrustworthy and violent position against the AngloSaxons (already an amalgam of races). The Spanish scholar condemns their disrespectful attitude for local rights and traditions, laws and institutions and the support they obtained from a corrupted Church ${ }^{21}$.

\footnotetext{
${ }^{19}$ Basically in early and non-official textbooks. Gaite (1874: 288) mentions the utmost cruelty of William I’s war of conquest. Similarly, Góngora (1882: 129) grants a negative image of William I, arguing against his violation of the Christian people's rights over their land.

20 Behind these approving remarks might hide the above-mentioned wish to drop the Anglo-Saxons and re-establish the late Middle Ages as the starting date of English history.

${ }^{21}$ Notwithstanding his fierce criticism of the Norman initial stages, Castro (1863-1872: vol III.: 206, 228-

32) elaborates further on this people in accordance with his optimistic faith in human progress and the
} 
To finish this concise analysis of results the presence of the Church as an Anglo-Saxon Other deserves some attention. As suggested above, traditional historians offer a very static view of Christianity, ignoring both the divergence between the truth-seeking model and its practitioners, and the existence of inner controversies. However, this is not always the case in our writings. Authors such as Puente, Moreno and most explicitly Castro offer a more dynamic representation of Christianity. Firstly, in their narratives the Christian domestic divisions are highlighted and serve as explanations of historical facts. In this connection Castro calls the reader's attention to the lack of homogeneity of Christian doctrine when portraying the Bretons (1863-1872: 137 vol. III) and blames Rome for abandoning the Celts at the time of the invasions. (See also Puente 1875: 31). Secondly, Christianity is not to be equated with its ministers, who are open to criticism. This means that whereas the cultural and socially amalgamating role of Christianity is acknowledged, the Church is portrayed as an Anglo-Saxon opposing Other, usually responsible for unwanted actions. Castro (1863-1872: 356-7 vol. II) charges against the moral degeneration of the clergy, and focuses on the opposing attitude of the people against their kings, disapproving of their monarchs' identification with the Pope's decisions. He also introduces ironic comments on the Christian habits of Anglo-Saxon converts; and severely criticises the Church as a political power which guarantees public acknowledgment (1863-1872: 190 vol. III) and “topples and crowns kings” (1863-1872: 197-200 vol. III). Condemning the attitude of a greedy Rome against (resisting) England, Castro (1863-1872: 192 vol. III) dismisses the virtues of Edward Confessor, recognizing him as blameworthy, despite canonization; and when comparing King Alfred and Charlemagne, Alfred turns up morally and globally "better” (1863-1872: 353 vol. II).

collective history that followed. In short, he explains the successful development of "two peoples of similar origin"... "bound to mutual understanding" ... "against France". 


\section{Concluding remarks}

The present research has proved that in nineteenth century Spanish history writing narratives on Anglo-Saxon Others are not faceless discourses. Much on the contrary, they prove biased by the historians' position along a cline ranging from a more conservative to a more progressive pole; or, in preferred academic terms, along a Roman-Germanic gradation. The position held by different writers affect not only the features ascribed to Anglo-Saxon Others, but also and most interestingly to their number.

It has also been demonstrated that both groups of historians offer a homogeneous negative image of Celts and Vikings, the Vikings remaining the Anglo-Saxons' strongest and most wicked Other. The reasons endorsing these renderings, however, differ from one group to the other.

The Normans receive a heterogeneous construal, being honoured by Torrente, Basté, Celebridades, Gómez Ranera and Enciclopedia and reviled by Castro, Puente, Moreno and Góngora. This makes the Normans a third Anglo-Saxon Other mainly in narratives subscribing a more Germanic line of thought. A fourth and revealing Other, the Church as an institution, comes up largely in Castro.

Most relevant and unexpected, results indicate that a different concept of race emerges from either type of narrative. For Roman historians race proves a static -territorial and religious- concept. It is (land and) religion that shapes the nation and peoples prove bound by links of origin. Conversely, for those writers distancing themselves from a Christian standpoint, the nation seems shaped by migration, assimilation becoming a key notion. Race would, thus, become a process, goal-bound concept. People become amalgamated by their collective destiny, their land acquiring a symbolic nature. Hence, it might be argued that the idea of organic, natural race is downplayed against the cultural idea of in-group, an ongoing achievement in which group boundaries are collectively generated. 
This research ultimately opens up new questions which might be worth exploring in future research on identity. Specifically, the idea that in history writing the portrayal of Others may admit a successive displacement of self, or the convenience to distinguish between main and secondary indexes of identity in the description of group representations.

References

Anderson, Benedict (1991). Imagined Communities. London: Verso.

Alonso Seoane, M.J. (2007). Nuevos datos sobre Agustín Pérez Zaragoza y algunos aspectos de la repercusión de su obra en prensa. XVI Congreso de la Asociación Internacional de Hispanistas (AIH). Universidad Paris-Sorbonne Paris IV.

Artola, M. 1973. La burguesía revolucionaria (1808-1869). Madrid: Alianza.

Åström B. 2002. The Politics of Tradition. Umeå Universitet.

Baena, Luis. 2003. “Semblanza de Don Manuel de Góngora y Martínez (1822-1884) y sus estudios sobre arqueología clásica”. Baetica. 25: 355-375

Bourdieu, Pierre (1980). "L'identité et la représentation". Actes de la recherche en sciences sociales 35: 63-70.

Carr, R. 1969. España 1808-1939. Barcelona: Ariel.

Delgado Idarreta, J.M. 1975. Los pronunciamientos liberales en Zaragoza durante la Regencia de María Cristina. Cuadernos de investigación. Geografía e Historia. Vol. 1(2), Edición electrónica. 
Delanty Gerard, Ruth Wodak, Paul Jones (Eds.) (2008) Migration, Identity, and Belonging Liverpool: Liverpool Univ. Press.

Foot, Sarah 2002: 'The making of Angelcynn: English identity before the Norman Conquest’. Liuzza R.M., ed. Old English Literature. Yale UP. 51-78. DOI: http://dx.doi.org/10.2307/3679228

Frank Roberta 1991, “Germanic Legend in Old English Literature,” Malcolm Godden and Michael Lapidge, eds. The Cambridge Companion to Old English Literature. Cambridge: Cambridge University Press: 88-106.

Frantzen, Allen J., 1990: Desire for Origins: New Language, Old English, and Teaching the Tradition. New Brunswick, NJ, and London: Rutgers UP.

Fundación Fernando de Castro. http://www.fernandodecastro.org/, last retrieved April 2012

García Puchol Joaquín 1993: Los textos escolares de historia en la enseñanza española: 1808-1900. Barcelona: Universitat

Laden, Sonja.1999."Greenblattian Self-Fashioning and the Construction of LiteraryHistory.’”, in Jürgen Pieters, ed. Critical Self-Fashioning: Stephen Greenblatt and the New Historicism. Frankfurt am Main: Peter Lang: 59-86.

Lavezzo, Kathy, 2006: Angels on the Age of the World: Geography, Literature, and English Community, 1000-1534. Ithaca and London: Cornell UP.

Nünnig, V. 2004. "The importance of being English: European perspectives on Englishness”. European Journal of English Studies 8: 145-158

Peiró, I. (1990): “La divulgación de la enseñanza de la historia en el siglo pasado: las peculiaridades del caso español” in Studium, n² 2, pp.107-133 
Peiró, I. (1993): “La difusión del libro de texto: autores y manuales de historia en los institutos del siglo XIX”, in Didáctica de las Ciencias Experimentales y Sociales, 7: $39-57$

Tejada, P. 2005. English Consciousness in 19th c Spain en C. Butler ed. The Dynamics of Language Use. Amsterdam: John Benjamins (369-92). (ISBN 978902725383 5)

Tejada, P. 2009. Salas y Quiroga's Anglo-Saxon England: a psychological and sociological portrait of power. Atlantis, .1 (June 2009): 73-90

Tejada , P. 2011a. Domesticating the past: Anglo-Saxon English origins in 19th c Spanish narratives. En Contreras Eugenio y Rodríguez Ana Laura, eds. Focus on Old and Middle English: Editorial Compluense. 93-116. ISBN: 97884 6942866-5

Tejada, P. 2011b La mujer germánica: popularización del pasado, exotismo ajeno y el nuevo concepto de igualdad en la España del siglo XIX. En Antón Pacheco, A. et al. eds. Estudios de mujeres. Diferencia, (des)igualdad y justicia. Differences, (in)equality and justice. Madrid: Fundamentos.223-234. Isbn: 978842451235-4

Tejada, P. 2011c. Nineteenth century images of English identity. Spanish translators and the will to change. Studies in Literature and Language, 2:2 (ISSN 1923-1555; 1923 1563). Pp 20-34

Tejada, P. 2011d. Territorial vs ethnic identity. Nineteenth century Spanish Renderings of the Anglosaxons. En Europe of Nations. Myths of Origin: Modern and Postmodern Discourses. CD Isbn 978-972-789-342-3.

Thomas, Hugh M. 2005: The English and the Normans: Ethnic Hostility, Assimilation, and Identity 1066-c.1220. Oxford UP

Valls Montés, R. 1999. "De los manuales de historia a la historia de la disciplina escolar: nuevos enfoques en los estudios sobre la historiografía escolar española”. Historia de la educación, 18: 169-190 
Primary Sources

Basté y Serarols, Juan.1888. Compendio de historia universal y particular de España. $3^{\circ}$ ed. Barcelona. Imprenta de J. Jepús.

Castro, Fernando de 1863-1872. Compendio razonado de Historia general. Publicación: Madrid: [s.n.], (Est. Tip. Gregorio Estrada) (vols II \& III).

Gaite y Nuñez, Joaquin 1874. Compendio de Historia universal y de España Publicación: Orense: [s.n.], (Imprenta de la Viuda de Lozano).

Gómez Ranera, Alejandro. 1871. Manual de historia universal, ó resúmen histórico de los principales estados de Europa, Asia, Africa y América, precedido de un extenso epítome de la historia sagrada Edición: 6a ed. corr. y aum. Publicación: Madrid : [s.n.], (Imp. de A. Gomez Fuentenebro).

Góngora y Martínez, Manuel de. 1882. Lecciones de historia universal. $2^{\circ}$ ed. Madrid, Est. Tip. de Góngora y Cía.

Moreno y Espinosa, Alfonso. 1881. Compendio de historia universal. Cádiz: Imprenta de la Revista Médica Federico Joly.

n.a. 1825-1826. Enciclopedia de la juventud : Compendio general de todas las ciencias... / Aumentada considerablemente por el traductor D.A. Zaragoza Godinez Publicación: Madrid: E. Aguado.

n.a. 1846. Celebridades del mundo: ó sea anales de todos los siglos, por órden cronológico y vidas de los hombres eminentes de cada siglo. Publicación: Madrid: Librería de la Sra. V. de Razola.

Puente y Villanúa, José. 1875. Manual de Historia Universal escrito para servir de texto... en la Facultad de Filosofía y Letras / por el Dr. D. José Puente y Villanúa Publicación: Zaragoza : [s.n.], (Imp. de Manuel Sola). 
tejada: others 104

Torrente, Mariano 1827-1828. Geografía universal física, política é historia. Publicación: Madrid: Miguel de Burgos.

Received: May 13, 2012

Accepted: October 26, 2012

Revised: November 2, 2012

Published: November 15, 2012 